\title{
Let's Kahoot! A game-based technology for creating engagement and promoting active learning
}

\author{
Perisya Hilmun, Fitriah \\ UIN Sunan Ampel Surabaya \\ mun.perisya@gmail.com
}

\begin{abstract}
Nowadays, the development of technology plays an essential role in many aspects of human life. People activity cannot be separated with the assistance of technology, including in education. Teachers often utilise technology to transform the information, make students motivated and engaged, and assess the progress of the learnt materials. Among the available technological tools, Kahoot is a digital game application that can be integrated into teaching. Teachers could use this application to promote active learning. This research aimed to explore the use of Kahoot in teaching as to increase students' engagement and encourage active learning. The study reviewed 18 published research papers identifying teachers' approaches in integrating Kahoot in their practices, the function and the effect of Kahoot in the classroom environment within EFL teaching. The result of review papers indicated that teachers utilised Kahoot to review and practice the learnt materials, and they used Kahoot at different times. All studies showed that the implementation of Kahoot could create a positive learning environment allowing students to participate actively. This study implies that teachers can integrate any digital game application into their teaching practices to make students engaged and promote active learning. However, teachers need to understand how to use the application correctly and identify whether the choice application is suitable for the students' level and needs.
\end{abstract}

Keywords: Kahoot, active learning, digital technology, EFL classrooms

\section{INTRODUCTION}

The integration of technology in teaching has become a common strategy that teachers apply when teaching in-person and virtual. The use of technology is even critical in the global pandemic as today. In this emergent situation, teachers are forced to conduct virtual learning and tackle these unexpected changes in their professional life. The question now is, how do teachers engage learners in efficient remote learning? It is challenging for every teacher because they have to change the method from analogue to digital teaching from one day to another. As said earlier, technology is an essential tool to transform information and conduct remote learning. Teachers can also use technology to encourage and motivate learners. For 
example, to make reading activities enjoyable, teachers may integrate the activity using an online application such as quillionz, naturalreaders, readlang, liveworksheets, and readingrockets. All of these application technologies are useful and interesting. Teachers could focus on specific skills that they need to improve with the variety of reading materials. Students could do the activity independently with the mentioned application's assistance instead of having printed texts or books.

Another way to make students engaged in learning is by using the game application. ReidGriffin and Slaten (2016) point out that the game plays an essential role in teaching and learning. Teachers can incorporate and adopt game-based learning practices through interactive technology in their teaching. The use of the game in the classroom can encourage students' participation and allow students to have learning experience (El-Nasr \& Smith, 2006). The multi-sensory and interactive nature of games can enhance students' involvement, problemsolving, and critical thinking abilities (McFarlane, Sparrowhawk, \& Heald, 2002). It is because they cannot move to the next level without completing the current mission or question. So, they should be able to finish the first question before moving to the next question.

Among the available digital game-based tools that teachers can use in their teaching, Kahoot is a popular educational application. Kahoot is a free website that allows teachers to create gamebased quizzes and surveys in which the participants compete against each other (Ismail et al., 2019; Johns, 2015). Scores are received based on the accuracy and response time, and students can see the result at the end of each answer (Johns, 2015). After completing all the questions, teachers could show the class scoreboard by displaying the top students' scores with correct answers. Studies revealed that the use of Kahoot could enhance students in doing classroom activity more efficient than using conventional media (Campillo-Ferrer, Miralles-Martinez, \& Sánchez-Ibáñez, 2020; Licorish, Owen, Daniel, \& George, 2018; Picka, 2017; Putri, 2019; Stige, 2016; Wang \& Lieberoth, 2016). A study by Picka (2017) in South Korean university found that students were excited participating in the digital game as they could receive prompt feedback after completing the quiz. They could also see the number of correct and wrong answers. Kahoot raised students' involvement and curiosity. Students could show their comprehension and knowledge without having a burden to speak aloud in the classroom. 
Similarly, Wang and Lieberoth (2016) explained that using the educational game-based tool as 'Kahoot' could influence focus, excitement, involvement, motivation, and performance in the teaching and learning process. Kahoot provides audio and music features that can significantly impact the active classroom environment (Chiang, 2020; El-Nasr \& Smith, 2006). Two studies found that teachers could use Kahoot as a platform to adjust teaching and tailor the students' level of knowledge by giving feedback on each question raised in the quiz (Licorish et al., 2018; Stige, 2016). Teachers could also focus on the problems that most students answer incorrectly. The utilisation of Kahoot in classroom practices is more useful, fun and engaging as students could actively participate in the whole session while learning the material through the game (Licorish et al., 2018).

Reflecting on the success of Kahoot in motivating and engaging learners' participation as discussed previously; however, not all teachers can use Kahoot and apply it in their classroom. They can apply it if the schools provide technology facilities such as good internet access, laptops, computers, and screen projector. In developing countries such as Indonesia, not all schools equipped with supported technological tools and the change and acceptance in technology use are very slow in English language classrooms (Mclnerney, Cheng, Mok, \& Lam, 2012). Some schools may facilitate technological tools, but teachers cannot integrate technology into the classroom. It is another problem that may hinder to conduct efficient learning. When teachers have to do remotely: how could they teach using technology, if they do not know how to use it correctly. This research aims to identify the use of Kahoot in classroom practices and its effect in the classroom environment. However, the study did not involve the teachers or do classroom observation to directly identify what the teachers do when applying Kahoot in their classroom practices. The current study examined the use of Kahoot by reviewing research articles. The review's focus was on identifying the findings of Kahoot implementation, the function and effect of Kahoot in the classroom. The papers reviewed were in the context of EFL classrooms practice.

\section{RESEARCH METHOD}

This study used a qualitative approach by doing a meta-analysis of the research papers (Shank, 2006). It is an effort to do a systematic and empirical secondary descriptive data of the primary investigation. The approach is suitable for this study as we intended to explore, understand, and interpret the data in-depth and detail (Creswell, 2014). The current study used a non- 
interactive qualitative method by only reviewing the research papers, and not do the research about the use of Kahoot directly in the classroom.

\section{Data Collection Technique}

This study's data was from the published articles or journals on the use of Kahoot within EFL context, which can be accessed online. The technique of collecting the data is similar to the content-analysis study reviewing the content of research published articles or papers. It is a structured method for recording examination or assessment in both written and digital (computer-based and internet-based) content (Strauss \& Corbin, 1998). The current study reviewed 18 research papers and elaborated the papers' findings to answer the research questions.

We did two steps in obtaining the papers: 1) using digital literature repositories to search appropriate studies; 2) reviewing the listed studies found. The keywords used in this analysis were Kahoot, active learning, and EFL classrooms. All the papers that emerge under the category were checked and identified to obtain the intended documents. The repositories we use are Google Scholar, Research Gate, Science Direct, Jstor, and other EFL online journals. In this step, the researcher needs to check the title and abstract of the articles. If an article accomplished all the inclusion and exclusion categories, we downloaded the full paper and added the citation data to the references. A total of 18 relevant articles from 38 papers were selected. Twenty items were rejected due to its unavailable access through full free payment and did not investigate students' responses, active learning, English language teaching.

\section{Data Analysis Technique}

We analysed the articles by categorising the findings according to the implementation of Kahoot and students' responses. For each item, we gave notes with the category:

1. Year of publication (2016 - 2019)

2. Country in which the study was conducted

3. Research Method and Procedures (e.g. quantitative, qualitative, classroom action research, mixed methods).

4. Context of the study (e.g. high school, middle school, higher education). 
Once, we gave notes on the data, then we classified and transferred into the table to further interpret the data. The classification of inclusion and exclusion criteria was listed to identify the relevant papers. The template of the inclusion and exclusion criteria were adapted from research by Wang and Tahir (2020).

\section{FINDINGS AND DISCUSSION}

\section{Findings}

The result of the review of 18 research papers indicated that teachers use Kahoot at different times, namely at the end of the meeting, at the beginning as icebreaking, and in the middle of the lesson after finishing one topic (see Table 1.1.).

Table 1.1. Results of previous studies on Kahoot implementation

\begin{tabular}{|c|c|c|}
\hline $\begin{array}{c}\text { Number of } \\
\text { articles }\end{array}$ & Research procedures & Strategy \\
\hline \multicolumn{3}{|c|}{ University level } \\
\hline 6 & Quantitative & $\begin{array}{l}\text { - Applying at the end as review, } \\
\text { assessment tool and ice breaker activity } \\
\text { - quizzes } \\
\text { - Applying at the beginning as ice } \\
\text { breaker or warm up activity }\end{array}$ \\
\hline 4 & Qualitative & $\begin{array}{l}\text { - Applying at the end as review and } \\
\text { assessment tools }\end{array}$ \\
\hline \multicolumn{3}{|c|}{ Secondary schools } \\
\hline 3 & Quantitative & $\begin{array}{l}\text { - Using at the end of the session to } \\
\text { evaluate students' understanding and } \\
\text { review the learnt materials }\end{array}$ \\
\hline 3 & Qualitative & $\begin{array}{l}\text { - Using at the end and main activity to } \\
\text { identify students' understanding or as } \\
\text { review tool }\end{array}$ \\
\hline 1 & Mixed methods & - Using at the end as a review tool \\
\hline 1 & Classroom action research & - Using at the end as a review tool \\
\hline
\end{tabular}

Table 1.1. describes that 18 studies used different approaches in identifying the use of Kahoot in classroom practices, namely: quantitative, qualitative, mixed methods, and classroom action research within the context of higher education and secondary school. The majority of the teachers used Kahoot at the end of the session to review or assess students' understanding of the learnt materials or topics. For example, a study by Yürük (2019) evealed that teachers used Kahoot after they completed three chapters. They discussed the topic by raising multipleEnglish Education: Jurnal Tadris Bahasa Inggris, Vol.14 (1), 2021, 94 
choice questions on Kahoot platform. At first, teachers explained the materials and students should answer 20 multiple-choice questions through Kahoot. Puspitasari, Mahfiana, and Pratolo (2019) found that the use of Kahoot was more engaging and exciting in evaluating the students' understanding.

Students did not feel that they did the test, and they enjoyed answering all the questions through Kahoot without worrying that they might make mistakes. Like Yürük's study, teachers used Kahoot after explaining several topics, and Kahoot was a review tool for teachers to identify the students' understanding of the subject. Rahmani (2017) surveyed 101 students in a Japanese University to determine the impact of Kahoot in students' learning achievement. The teacher used Kahoot to practice vocabulary by combining multiple choices and true or false questions. Every student competed with their classmates to be the winner to obtain the first rank. The students participated actively in the quiz. They were all focus on their gadget, trying to answer the questions. These examples describe how teachers use Kahoot at the end of the session. Chiang (2020) reported that teachers used Kahoot twice in their classroom practices: at the beginning as an ice breaker or warm-up activity and the end as a review tool. Interestingly, the teacher told the students that the Kahoot quiz scores would not contribute to their final grade.

Most of the articles reviewed indicated that the use of Kahoot could promote active learning and enhance students' involvement and participation (see Table 1.2). The findings noted positive effects of the Kahoot implementation, such as encouraging students' motivation, creating an enjoyable learning atmosphere, promoting cooperation and collaboration, and facilitating language improvement.

Table 1.2. Effect of Kahoot in classroom environment

\begin{tabular}{|l|l|}
\hline \multicolumn{2}{|c|}{ Effect of Kahoot in classroom environment } \\
\hline - $\begin{array}{l}\text { Create positive attitudes } \\
\text { Encourage students' interest \& } \\
\text { motivation }\end{array}$ & - Eromoting cooperation \& collaboration \\
- $\begin{array}{l}\text { Creating enjoyable learning environment } \\
\text { Enhancing students' participation \& } \\
\text { involvement } \\
\text { Transforming the class into student } \\
\text { center learning }\end{array}$ & - Facilitating language improvement \\
& \\
\hline
\end{tabular}


Chiang (2020) reported that students were very excited and motivated in doing classroom activity: “Kahoot enhance students' positive responses, increase their motivation, stimulate a better understanding of the lesson (Teacher A)". Another teacher believed that Kahoot was an excellent choice for college students as they had access to PC or mobile devices with an Internet connection. Kahoot could encourage curiosity and enthusiasm, and teachers could identify the students' participation through the platform (e.g. active and passive students). Another research paper revealed that Kahoot could create an enjoyable and exciting classroom environment (Licorish et al., 2018). All students enjoyed using Kahoot without realizing that what they did was part of the discussed topic's progress assessment.

The reasons for using Kahoot in the classroom were determined through a survey of $101 \mathrm{EFL}$ students in Japan. Participants noted that when compared to paper-based exercises, mobile applications can foster peer collaboration, increase engagement during the teaching-learning process, empower students' spirits, and alleviate boredom. The lesson became more enjoyable and interesting as a result. As a result of their enthusiastic participation, students are likely to compete with one another. They make an attempt to address all questions and provide the best response possible. Everyone pays attention to the game without realising they are gaining knowledge.

\section{Discussion}

The review papers concluded that there was a positive effect on the use of Kahoot as a tool for engaging students and promoting active learning. The scientific framework within which Kahoot games are designed falls into three categories: 'fantasy, challenge, and curiosity' (Campillo-Ferrer et al., 2020). Kahoot's fantasy element transforms the classroom into a game show, with the teacher as the host and the students as contestants. Teachers could enhance the fantasy by including audio, images, videos, and a podium so that students can imagine themselves competing in a competition and competing against one another for a spot on the highest stage. According to some studies, 'game show elements' such as a scoreboard or points can contribute to the creation of a more positive learning environment. As a result, students are motivated and intrigued to win the game. The primary reason for incorporating this tool into teaching is to instil a sense of excitement and competition in students. 
As described at the outset, teachers use different ways of integrating Kahoot in the classroom activity. The main point of the finding is that Kahoot does not teach the material. Kahoot is a tool to transform questions excitingly and engagingly. That is why all studies reported that teachers used Kahoot as a review and assessment tool of the learnt materials. They used it after explaining the lesson, the Kahoot platform questions relate directly to the discussed topic. Some scholars believe that the combination of game and technology can be used as a warmer activity to make students engaged and motivated (Hsieh, Scott, Wu, \& Marek, 2016). The teachers may have the same purpose to engage students in their classroom activities when using Kahoot.

However, not all teachers can apply the Kahoot application effectively. The school facility is crucial in implementing technology in the classroom. This applies for Kahoot application, and other online applications require internet access, and it needs supportive facilities. Another essential element is the teachers' ability in using technology. Technology will not have any meaning in classroom practices if the teachers do not know how to use it properly. Therefore, teachers need to select the available technology that they are familiar with. The main thing is that they can achieve the teaching purposes, and students can learn something from the activity even using simple technology. The studies identified that the way teachers use Kahoot is mostly the same: at the conclusion of the session as a means of evaluating and reviewing the learned materials. The teacher need only to create the questions and upload them to the Kahoot platform. It makes no difference how teachers use Kahoot; what matters is that they understand how to use it properly and how it fits into classroom practises. As previously stated, the purpose of Kahoot is to elicit student participation through the use of audio visuals, graphs, and a competitive vibe.

Even though most studies indicated positive responses toward the use of Kahoot in classroom practices, some papers revealed a challenge in using the Kahoot, mainly dealing with the school facility. It makes sense as there is a considerable discrepancy in terms of facility and education quality in Indonesia. For example, teachers in urban can integrate Kahoot in their teaching as they have all supported facilities for doing the activity. Still, some schools in the countryside are not the case. They need to work extra to get, such as Internet access and gadget for doing the activity. Therefore, teachers should select possible technology that students can do. The majority of the results from any different educational stages showed that the application of English Education: Jurnal Tadris Bahasa Inggris, Vol.14 (1), 2021, 97 
Kahoot could significantly help students be more active in learning. At the same time, they still have fun when playing and learning. One of the critical factors of Kahoot is the social support that takes place both in the digital game and in the classroom (Hsieh et al., 2016). In line with Stige's opinion (2016), gamification and technology can create an enjoyable experience, and teachers should maximise interaction, engagement, and involvement. The integration of digital technology in learning can enhance students' attention and create a pleasant learning environment when teachers know how to use it (Johns, 2015). The educational game incorporates an intrinsic motivation component that fosters curiosity and gives students the impression that they are in control of their education (Mclnerney et al., 2012). Indeed, students express that they enjoy this assignment because it requires them to think creatively about how they can use technology in a learning environment. Students do not need to register in order to use the application; they simply need to open the website and enter the code to participate in the quiz. Additionally, if students are unable to correctly answer the questions, they can use initial or anonymous responses, which ensures that no one knows they made a mistake. It may be advantageous for students who do not want their classmates to learn about their flaws.

Another effect of Kahoot application is encouraging students' participation in learning since Kahoot is competition and quiz show. Students will focus on their gadgets to think and answer questions to obtain the first rank. Licorish et al. (2018) point out that active learning is an essential characteristic involves students to judge and criticise something. When teachers use Kahoot, students are inevitably forced to think fast and find the correct answer. However, it will not work effectively if the students do not have an interest in learning. They may be passive and uninterested in participating in the activity.

\section{CONCLUSION AND SUGGESTION}

\section{Conclusion}

The result of reviewed papers highlighted that the use of Kahoot brings positive responses in the classroom atmosphere, especially for motivating and enhancing students' participation. In teaching young learners, it is essential to encourage students engaged in learning. Because when they are motivated, it will be easier to transform the information. However, it is not always the case in higher education; they come to the classroom to learn not doing the game. Teachers should consider whether the game application they use is helping students understand 
not just having fun. Therefore, teachers should consider the purpose and function of any technology they use in the classroom. Another important point from the finding of this study is that assessing students is an ongoing process. Making assessment interesting and enjoyable can assist students who are experiencing test anxiety in developing confidence in their abilities and self-esteem. Kahoot is one of the applications available to teachers for tracking their students' progress. The website is an excellent assessment tool that can be integrated into any classroom to help students learn more effectively through motivation and real-time assessment.

\section{Suggestion}

This research is not perfect. There should be follow-up study in identifying the use of Kahoot in classroom practices by doing classroom observation and interviewing the teachers on the approaches and strategies they use when implementing Kahoot. It will be interesting to find out how teachers use technology in the global pandemic today: what technology they use and the challenges in using the technology.

\section{REFERENCES}

Campillo-Ferrer, J.-M., Miralles-Martinez, P., \& Sánchez-Ibáñez, R. (2020). Gamification in higher education: Impact on student motivation and the acquisition of social and civic key competencies. Sustainability, 12(1), 1-13.

Chiang, H.-H. (2020). Kahoot! in an EFL reading class. Journal of Language Teaching and Research, $11(1), 33-44$.

Creswell, J. W. (2014). Research design: Qualitative, quantitative and mixed methods approaches (4 ed.). California: SAGE Publications.

El-Nasr, M. S., \& Smith, B. K. (2006). Learning through game modding. Computers in Entertainment, 4(1), 4-7.

Hsieh, C., Scott, J., Wu, W.-C. V., \& Marek, M. W. (2016). Using the flipped classroom to enhance EFL learning. Computer Assisted Language Learning, 30(1), 1-21.

Ismail, M. A.-A., Ahmad, A., Mohammad, J. A.-M., Fakri, N. M. R. M., Nor, M. Z. M., \& Pa, M. N. M. (2019). Using Kahoot! as a formative assessment tool in medical education: A phenomenological study. BMC Medical Education, 19(230), 1-8.

Johns, K. (2015). Engaging and assessing students with technology: A review of Kahoot. Delta Kappa Gamma Bulletin, 81(4), 89-91.

Licorish, S. A., Owen, H. E., Daniel, B., \& George, J. L. (2018). Students' perception of Kahoot!'s influence on teaching and learning. Research and Practice in Technology Enhanced Learning, 13(9), 1-9. 
McFarlane, A., Sparrowhawk, A., \& Heald, Y. (2002). Report on the educational use of games. Retrieved from Cambridge: www.teem.org.uk

Mclnerney, D. M., Cheng, R. W.-y., Mok, M. M. C., \& Lam, A. K. H. (2012). Academic self-concept and learning strategies: Direction of Effect on student academic achievement. Journal of Advanced Academic, 23(3), 249-269.

Picka, K. (2017). Digital games in education from the perspective of teachers. Journal of Technology and Information Education, 9(1), 156-168.

Puspitasari, E., Mahfiana, A. M., \& Pratolo, B. W. (2019). Students' perception toward interactive game to facilitate students' achievement. Science, Technology, Engineering, Economics, Education, and Mathematics, 1(1), 1-8.

Putri, A. R. (2019). The effectiveness of using Kahoot game to improve students' vocabulary comprehension. (Master Degree), Universitas Negeri Semarang, Semarang.

Rahmani, M. (2017). The use of smartphone as a learning tool among 2nd year EFL students at Tlemcen University: What is there and what is missing? (Master Degree), University of Tlemcen, Algeria.

Reid-Griffin, A., \& Slaten, K. M. (2016). Wikis: Developing pre-service teachers' leadership skills and knowledge of content standard. European Journal of STEM Education, 1(1), 1-9.

Shank, G. D. (2006). Qualitative research: A personal skills approach (2 ed.). Upper Saddle River, NJ: Merrill.

Stige, S. H. (2016). Kahoot! as a tool for adjusting teaching to atch students' knowledge level and promoting active learning in a lecture setting. Journal of Medicine, 1(1), 1-9.

Strauss, A. L., \& Corbin, J. M. (1998). Basics of qualitative research: Techniques and procedures for developing grounded theory (2 ed.). Thousand Oaks: Sage Publications.

Wang, A. I., \& Lieberoth, A. (2016). The effect of points and audio on concentration, engagement, enjoyment, learning, motivation, and classroom dynamics using Kahoot. European Conference on Games Based Learning, 1(1), 738-745.

Wang, A. I., \& Tahir, R. (2020). The effect of using Kahoot! for learning - a literature review. Computers and Education, 149(1), 1-9.

Yürük, N. (2019). Edutainment: Using Kahoot! as a review activity in Foreign Language Classrooms. Journal of Educational Tecchnology and Online Learning, 2(2), 89-101. 